\title{
Editorials for advances in agriculture and environmental science
}

\author{
Medani P Bhandari \\ Akamai University, Hawaii, USA
}

Correspondence: Medani P Bhandari, Department of Natural Resource \& Environment / Sustainability Studies, Akamai University, Hawaii, USA, Tel 3 I 78748272, Email medani.bhandari@gmail.com, mbhandar@syr.edu

Received: February 04, 2018 | Published: March 15, 2018

Copyright@ 2018 Bhandari. This is an open access article distributed under the terms of the Creative Commons Attribution License, which permits unrestricted use, distribution, and reproduction in any medium, provided the original author and source are credited.

\section{Editorial}

Welcome to the Journal of Advances in Agriculture and Environmental Science.

"Climate change has potential to damage irreversibly the natural resource base on which agriculture depend, with grave consequences for food security. ... The problems of climate change, hunger and poverty, economic, social and gender inequity, poor health and nutrition, and environmental sustainability are inter-related and need to be solved by leveraging agriculture's multi-functionality."

"Documented increases in global air and sea temperatures over the last century have demonstrated unequivocally that our planet is warming. Most climatologists agree that the warming trend will continue, and at an accelerating pace unless the causes of global warming are addressed immediately. This reality, and the urgent need for action, is finally being recognized by society and governments around the world."

There is inevitable relationship between agriculture and environment [the surroundings or conditions in which a person, animal, or plant lives or operates (it also covers, climatic condition, its pattern and change). ${ }^{3}$ Human existence and civilization began with the development of agriculture which fully relies on climatic variations of specific locations of Earth surface. All of us have been witnessing the variation and change in climate in one way or another. With no doubt, We, humans are directly or indirectly responsible and have been contributing to this climate change, wherever we live or whatever do; however, the degree of contribution and impact may vary.

"Human influence on the climate system is clear, and recent anthropogenic emissions of greenhouse gases are the highest in history. Recent climate changes have had widespread impacts on human and natural systems. Warming of the climate system is unequivocal, and since the 1950s, many of the observed changes are unprecedented over decades to millennia. The atmosphere and ocean have warmed, the amounts of snow and ice have diminished, and sea level has risen." "Anthropogenic greenhouse gas emissions have increased since the pre-industrial era, driven largely by economic and population growth, and are now higher than ever. This has led to atmospheric concentrations of carbon dioxide, methane and nitrous oxide that are unprecedented at least the last 800,000 years. Their effects, together with those of other anthropogenic drivers, have been detected throughout the climate system and are extremely likely to have been the dominant cause of the observed warming since the mid20th century." 4

Thousands of scholarly publications and evidences (in the forms of scientific papers, books, reports, and opinions etc.) show that the change in climate, has direct impact (mostly negative) on agriculture and other life-support ecosystems of the Earth surface. "The longterm good health of populations depends on the continued stability and functioning of the biosphere's ecological and physical systems, often referred to as life-support systems. ... The world's climate system is an integral part of this complex of life-supporting processes, one of many large natural systems that are now coming under pressure from the increasing weight of human numbers and economic activities."

These publications also clearly demonstrate that there is an urgency to take actions to minimize / stop / mitigate such changes in climate for a healthy planet. As a matter of fact, many initiatives and steps have been taken from the international to individual levels [various international treaties, policies, actions etc., one recent example is the Paris Agreement, which "entered into force on 4 November 2016, thirty days after the date on which at least 55 Parties to the Convention accounting in total for at least an estimated $55 \%$ of the total global greenhouse gas emissions have deposited their instruments of ratification, acceptance, approval or accession with the Depositary". 6 At the individual level, the behavioral changes such as recycling, tree plantation, sharing and caring, raising awareness on how sea-level rise will affect, advocating, acting, teaching, researching and publishing or publicizing how climate change is affecting humans etc. are a few examples. However, still there are unmeasured and unexplored issues on how climate change has already impacted and will affect the life-support ecosystems (in particular on agriculture and by agriculture). There is a strong need of research by individuals and broad interdisciplinary collaboration within and beyond the spectrum of environment and agriculture.

This journal aims to fulfill this need by bringing scholars from north and south. This opening issue welcomes constructive comments and calls for scientific research papers on climate change, agriculture, food
Submit your Article | www.ologypress.com/submit-article OP $\underset{\text { Press }}{\text { Ology } f \text { in } y \text { witio }}$
Citation: Bhandari MP. Editorials for advances in agriculture and environmental science. Adv Agr Environ Sci. (20I8); I(I): 49-50. DOI: I0.3088I/aaeoa.00008 
production, agroforestry, ecology, environment, earth and resource management, sustainability or any research within the domain of Agriculture and Environmental Science.

\section{References}

1. UNCTAD V. Wake up before it is too late. Make agriculture truly sustainable now for food security and changing climate. Trade and Environment Review. 2013.

2. Kleinschmit J. Agriculture and Climate-The Critical Connection“. Report written for The Institute For. 2009.
3. Dictionary B. Business dictionary. Retrieved April. 2012;17:2012.

4. Pachauri RK, Allen MR, Barros VR, et al. Climate change 2014: synthesis report. Contribution of Working Groups I, II and III to the fifth assessment report of the Intergovernmental Panel on Climate Change. IPCC. 2014.

5. McMichael AJ. Climate change and human health: risks and responses. World Health Organization. 2003.

6. https://www.mitpressjournals.org/doi/abs/10.1162/GLEP_a_00361 